\title{
Reporting Africa
}

\author{
Baffour Ankomah
}

When opening this conference, Professor Lizette Rabe quoted a statistic that struck a chord with me.

In a six-month period between March and August 2000, the TransAfrica Forum in the USA had counted 89 stories on Africa published by The New York Times and Washington Post. Of the 89, 75 were negative, and 63 of the 89 were about conflict in Africa.

What this statistic does is to portray in a small way the massive problem of how Africa is reported by the Western media, and which we, the African media, sometimes reflect and amplify in our reporting of the continent, by mimicking the Western media.

No right-thinking African will ever deny that conflict does happen in Africa. However, the problem with the negative reporting is that it does not put the raw facts in context.

Africa is a continent of 53 countries. It is the most variegated continent on Earth. Conflict is part and parcel of human nature, of life. In that context, Africans would not be human if conflict did not happen on this huge, variegated continent.

By contrast, Western Europe, by landmass, is smaller than the DR Congo, the second largest country in Africa. I have checked the sizes in the atlas. You can fit the original 12 members of the European Union into the DR Congo, and you still get over 4,000 square miles left to be given to the descendants of King Leopold for free.

Africa is that big. And it beggars belief that respectable journalists and media houses in the West can ever think that in this vastness of space called Africa, no conflict should happen.

After all, since when did inter-tribal wars stop happening in Europe? Europe, small as it is, is the continent with the most violent history in the world.

Until 1945, when the Second World War (which some have described as the Second Pan-European War) ended, history shows that war in Europe was like going to the supermarket to buy groceries. The frequency of wars in Europe was such that one leader is credited to have admonished his people in these famous words: 'In times of peace, prepare for war'.

Intra-European wars only abated when the USA introduced the atomic bomb into the theatre of war in 1945. So please, let's have some context.

But you can't find context about Africa in the Western media because of a multiplicity of factors. Because of the time factor, I will only mention four of them this morning:

The first, and most enduring, is 'historical baggage'. In 1999, George Alagiah, the BBC newscaster and former Africa correspondent, defined historical baggage as: 'The $20^{\text {th }}$ century view of Africa infected with the prevailing wisdom of the $19^{\text {th }}$ century.'

On 3 May 1999, Alagiah wrote a piece for The Guardian [of London] in which he pleaded with his 
colleagues in the Western media to drop the historical baggage drivel.

Please let me quote you parts of what Alagiah wrote:

For most people who get their view of the world from TV Africa is a faraway place where good people go hungry, bad people run government, and chaos and anarchy are the norm. My job is to give a fuller picture. [But] I have a gnawing regret that, as a foreign correspondent, I have done Africa a disservice, too often showing the continent at its worst and too rarely showing it in full flower. There is an awful lot of historical baggage to cut through when reporting Africa: the $20^{\text {th }}$ century view of the continent is, even now, infected with the prevailing wisdom of the $19^{\text {th }}$ century. Take this description of an African from a speech given by the [British] explorer John Hanning Speke in the 1860s:

'As his father did, so does he. He works his wife, sells his children, enslaves all he can lay his hand upon, and unless fighting for the lands of others, contents himself with drinking, singing, and dancing like a baboon, to drive dull care away' [description of the African by John Hanning Speke in 1860].

And Alagiah said in 1999:

It's an ugly thought, but I would bet one of my new suits that there are many out there [today] for whom those words still have resonance. I take this personally because I spent part of my childhood in Africa [in Ghana actually]. After Britain, Africa is probably the place I feel most at home. I know it to be a place of great passion and variety. Above all, it is a place where the outsider is forever welcome. In the hardest of times and in the most desolate of places, I have been greeted with a warm hand and an open heart. I had reason to remember this when reporting from Albania recently. I am no expert on European affairs, and it came as a shock that there was somewhere as poor as Albania in this continent [of Europe]. But what I found more surprising, and disturbing, was the lack of joie de vivre [in Albania]. Whereas even in the most poverty stricken and politically oppressed corner of Africa, there is irrepressible vein of hope and humour that bubbles to the surface. Perhaps, this is what Ben Okri had in mid in his poem, An African Elegy: 'We are the miracles that God made/To taste the bitter fruit of time/We are precious/And one day our suffering/Will turn into the wonders of the earth'.

It is a noble sentiment but not one you will easily glean from my reporting [of Africa]. There has been too much of Africans as victims, and not enough showing their daily triumphs against impossible odds.

Interestingly, after such brilliant writing, The Guardian chose to headline Alagiah's article 'New Light on the Dark Continent'.

Even when Alagiah was pleading that 'historical baggage' should be dropped, The Guardian, in its infinite mercy, still put the abominable 'Dark Continent' headline on the very article in which Alagiah was making his plea.

And therein lies the problem of the negative reporting of Africa: the inability of the $21^{\text {st }}$ century Western journalist and their giant media houses to drop the historical baggage about Africa! This is the main reason why much of their coverage of Africa is negative.

And this is why The Economist, which prides itself in being the 'house journal of globalisation' could do a front cover story on Africa on 13 May 2000 and title it: 'The Hopeless Continent'.

In the summer of 2002, I was invited to a media retreat outside London organised by a group that wanted to bring a change to how Africa and other 'faraway places' were reported in the British 
media.

Senior British editors, correspondents, and journalism teachers and trainers (like yourselves) were brought together at this weekend retreat to talk about how they report Africa and what they could do to improve it.

What I heard for those three days nearly blew my mind. It was there that I learned for the first time that the 'British media report into a box'. And the box contains pre-set ideas. So if a correspondent returns from Africa with a story, or sends a story from Africa, and it does not fit the box, one of two things happen: One, it is edited to fit the box; or two, it is thrown into the dustbin. In that circumstances, as one correspondent from a major daily newspaper based in London told the conference, correspondents who want to see their stories published, are forced to conform to the box.

That is why, Alagiah, after spending three or so years in Africa as a $B B C$ correspondent could say at the end of it that:

I know [Africa] to be a place of great passion and variety. Above all, it is a place where the outsider is forever welcome. In the hardest of times and in the most desolate of places, I have been greeted with a warm hand and an open heart... but [it is not something] you will easily glean from my reporting [even though]... "my job is to give a fuller picture. [But] I have a gnawing regret that, as a foreign correspondent, I have done Africa a disservice, too often showing the continent at its worst and too rarely showing it in full flower.

He needed his bylines. His stories had to run on BBC-TV, so even though he spent part of his teenage years in Ghana, and knew the continent well, he could not report Africa in "full flower" when he had the chance to, as a foreign correspondent.

Alagiah's dilemma is shared by all Western correspondents who come to Africa or write about Africa. Just watch them. If he or she arrives in Stellenbosch, for example, after all the beauty of this town, the first place he will touch will be the slums on the edges of the city. He or she will never write about the beauty of the campus of the University of Stellenbosch, which you cannot find in many countries of Europe. Hardly can you come across in Europe a university campus that has the space and beauty of Stellenbosch University. And yet, you can bet your bottom rand on it, that the Western journalist will not see that as worthy of reporting, because the box back home in his newsroom says if he did that story, it would not be published.

The second factor affecting the reporting of Africa in the Western media is what my colleague Stella Orakwue has defined as 'the comfort zone'.

Africa has become the 'comfort zone' used by the West to calm down their restless masses. The trick is simple: portray Africa in the most negative light, show African refugee children with flies flying around their mouths, their stomach distended, their parents living in huts, and Western NGO workers at the rescue - the more these images are shown, the more it works on the masses in the West, however poor they are, they are left with one response: 'Oh, I am better than these wretched Africans. Thank God.'

In that state of mind, even if this ordinary Westerner is rotting in his hellhole, as some do, he takes comfort from the fact that some people in Africa are far worse off than he is, so the edge to demand more from his government is blunted.

In the same vein, if the Western media portrays the Tanzanian capital, Dar es Salaam, or the Nigerian capital Abuja in full flower, the West's 'comfort zone' becomes threatened, in that the ordinary Westerner who has forever been fed with the idea that Africans live in huts (and sometimes in trees), will see that the African is not so badly off after all. So they won't show our cities and towns in full flower. They would show only the slums. 
The third point is economic. In today's globalised world, where everybody is fighting for a place in the economic sun, a positive portrayal of Africa in the Western media will mean that Africa, on whose natural resources Western economies depend, may get more investments and may even dare to use its resources for itself.

In 1999, I was in Malaysia to hear the then prime minister Mahathir Mohammed, say exactly that at an Asia-Africa Business Forum. His exact words were: 'When we were all struggling for a place in the economic sun, Western investors came here to invest, which became the engine of our growth. That is what Africa has missed out.'

In fact, in the American national security document, NSM 200 of 1974, which advocated for the control of the African population, one of the reasons cited for controlling our population is that the Western nations depend on Africa resources for their economic survival, and if the African population was allowed to grow unchecked, 'Africa may use its natural resources for itself or ask for better terms of trade'.

I have always asked the question: 'You are an investor, with a pot of gold, looking for somewhere to invest this money, and suddenly this week's Economist magazine falls on your table, with the front cover headline: 'The Hopeless Continent', would you ever consider Africa as a place to invest your money or even take a holiday?'

Last year, the Rwandan president, Paul Kagame, actually admitted that: 'The constant negative reporting of Africa kills the growth of foreign direct investment. There has even been a suggestion that it is meant to keep Africa in the backyard of the global economy.'

On another level (and it is the fourth factor I will talk about today), the negative portrayal aims at making Africans fell self-pity and self-hate, to loathe themselves and their heritage. These feelings are dangerous, because it makes you wonder, sometimes, why God created you, this wretched African. It is psychological warfare.

I will cite two mundane examples: you meet African teenagers born in the UK and you ask them where they come from, the stock answer is: 'My mum comes from Nigeria or Kenya or Ghana, but I am British.' They don't want any association with Africa, because of the wretchedness they see about Africa on TV, in the newspapers and at school.

On the other hand, until Jennifer Lopez came up with her so-called 'African bum', we did not ever see any articles in the Western media extolling the virtues of the African feminine backside. But we all know that since Adam, the African woman has forever had this endowment, yet she never won the Miss World title.

Since the emergence of Jennifer Lopez, I have seen documentaries on British TV and long articles in the newspapers about how Western women are paying over the odds to cosmetic surgeons to inject fatty tissues into their bums, just so they will catch a bit of the African endowment to enhance their looks when they wear their jeans.

Mr Chairman, please let me stop here before I am carried away.

I thank you.

\section{About the speaker}

Baffour Ankomah is editor of the New African 